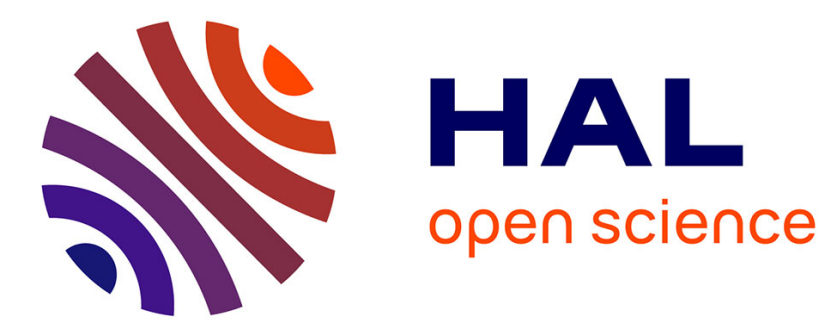

\title{
Thermal imprint of rift-related processes in orogens as recorded in the Pyrenees
}

Arnaud Vacherat, Frédéric Mouthereau, R Pik, M Bernet, C Gautheron, E Masini, Laetitia Le Pourhiet, B Tibari, Abdeltif Lahfid

\section{- To cite this version:}

Arnaud Vacherat, Frédéric Mouthereau, R Pik, M Bernet, C Gautheron, et al.. Thermal imprint of rift-related processes in orogens as recorded in the Pyrenees. Earth and Planetary Science Letters, 2014, 408, pp.296 - 306. 10.1016/j.epsl.2014.10.014 . hal-01089948

\section{HAL Id: hal-01089948 \\ https://hal.sorbonne-universite.fr/hal-01089948}

Submitted on 2 Dec 2014

HAL is a multi-disciplinary open access archive for the deposit and dissemination of scientific research documents, whether they are published or not. The documents may come from teaching and research institutions in France or abroad, or from public or private research centers.
L'archive ouverte pluridisciplinaire $\mathbf{H A L}$, est destinée au dépôt et à la diffusion de documents scientifiques de niveau recherche, publiés ou non, émanant des établissements d'enseignement et de recherche français ou étrangers, des laboratoires publics ou privés. 


\section{Thermal imprint of rift-related processes in orogens as recorded in the Pyrenees}

\section{A. Vacherat ${ }^{1,2,3}$, F. Mouthereau ${ }^{1,2, *}$, R. Pik ${ }^{3}$, M. Bernet ${ }^{4}$, C. Gautheron ${ }^{5}$, E. Masini ${ }^{6}$, L. Le Pourhiet $^{1,2}$, B. Tibari ${ }^{3}$, and A. Lahfid ${ }^{7}$}

${ }^{1}$ Sorbonne Universités. UPMC Univ Paris 06, UMR 7193, Institut des Sciences de la Terre Paris (iSTeP), 4 Place Jussieu, F-75005 Paris, France (arnaud.vacherat@upmc.fr)

${ }^{2}$ CNRS, UMR 7193, Institut des Sciences de la Terre Paris (iSTeP), 4 Place Jussieu, F-75005 Paris, France

${ }^{3}$ CRPG, UMR 7358 CNRS-Université de Lorraine, BP20, 15 rue Notre-Dame des Pauvres, 54500 Vandoeuvre-lès-Nancy, France

${ }^{4}$ Institut des Sciences de la Terre (ISTerre), Univ Joseph Fourier, CNRS, 1381 rue de la piscine, Grenoble 38041, France

${ }^{5}$ Univ Paris Sud, UMR GEOPS-CNRS 8148, Bâtiment 504, Rue du Belvédère, 91405 Orsay, France

${ }^{6}$ TOTAL, CSTJF, Avenue Larribau, 64016 Pau, France

${ }^{7}$ BRGM/MMA/MIN, 3 avenue Claude Guillemin, 45060 Orléans Cedex 2, France

*Now at Université Toulouse III - Paul-Sabatier, Laboratoire Géosciences Environnement Toulouse, UMR 5563, 14 av. Edouard Belin, F-31400 Toulouse, France

\section{Abstract}

The extent to which heat recorded in orogens reflects thermal conditions inherited from previous rift-related processes is still debated and poorly documented. As a case study, we examine the Mauléon basin in the north-western Pyrenees that experienced both extreme crustal thinning and tectonic inversion within a period of $~ 30$ Myrs. To constrain the timetemperature history of the basin in such a scenario, we provide new detrital zircon fissiontrack and (U-Th-Sm)/He thermochronology data. The role of rift-related processes in subsequent collision is captured by inverse modeling of our thermochronological data, using relationships between zircon (U-Th-Sm)/He ages and uranium content, combined with thermo-kinematic models of a rift-orogen cycle. We show that the basin recorded significant heating at about $100 \mathrm{Ma}$ characterized by high geothermal gradients $\left(\sim 80^{\circ} \mathrm{C} / \mathrm{km}\right)$. Our thermo-kinematic modeling and geological constraints support the view that subcontinental 
lithospheric mantle was exhumed at that time below the Mauléon basin. Such a high geothermal gradient lasted $30 \mathrm{Myr}$ after onset of convergence at $83 \mathrm{Ma}$ and was relaxed during the collision phase from $50 \mathrm{Ma}$. This study suggests that heat needed for ductile shortening during convergence, is primarily inherited from extension rather than being only related to tectonic and/or sedimentary burial. This should have strong implications on tectonic reconstructions in many collision belts that resulted from inversion of hyper-extended rift basins.

\section{Introduction}

The steady-state thermal structure of collisional orogenic belts is controlled by upward advection of heat through the coupling between crustal shortening and erosion (Royden, 1993; Stüwe et al., 1994; Willett and Brandon, 2002). However, considering typical thermal relaxation time of several 100 Myrs for thick lithospheres (Jaupart and Mareschal, 2007), transient effects might not be negligible for continental margins that experienced both thermal resetting during thinning and structural inversion over a relatively short period of time (Mouthereau et al., 2013). This process might be even more significant for inverted distal margins that have experienced extreme crustal thinning and mantle exhumation (Manatschal, 2004). The pre-orogenic temperature anomalies caused by crust/subcontinental lithospheric mantle (SCLM) thinning, may therefore significantly impact the thermal history and thermaldependent ductile mechanisms of deformation in orogens, but their magnitude has yet to be constrained. For instance, Mesalles et al. (2014) using low-temperature thermochronological data in southern Taiwan demonstrated that an originally hot distal margin may record cooling only 20 Myrs after the end of rifting due to the onset of continental accretion.

Here, we focus on the Pyrenees, where geochronological and petrographic constraints indicate that rifting exhumed the SCLM in Albian times (ca. 110 Ma) (Vielzeuf and Kornprobst, 1984; Lagabrielle and Bodinier, 2008; Jammes et al., 2009; Lagabrielle et al., 2010; Clerc et al., 2012) while plate convergence initiated at 83 Ma (Rosenbaum et al., 2002). The Mesozoic Mauléon basin in the north-western Pyrenees (Fig. 1A) is interpreted as a preserved hyper-extended rift system formed during the Late Aptian - Early Albian, above a low-angle detachment system (Johnson and Hall, 1989; Jammes et al., 2009; Masini et al., 2014). This is supported by field evidences of breccias of mantle peridotites reworked in syn-/post-rift sediments of Albo-Cenomanian age, or tectonically overlying the granulitic complex of the Labourd-Ursuya Massif (Jammes et al., 2009). 
To establish the time-temperature history of the Mauléon basin, we inverse modeled detrital zircon fission-track and (U-Th-Sm)/He thermochronological data collected for this study. Model results were then compared to thermal patterns predicted from a 1D thermo-kinematic numerical model of the evolution of hyper-extended rift basins that are inverted during collision. Our results reveal that high geothermal gradients, inherited from hyper-extension, are maintained over 30 Myrs after convergence initiated.

\section{Hyper-extension in the Pyrenees and thermal constraints}

The Pyrenean belt resulted from the inversion of previously extended domains of the Iberian and European plates from the Late Cretaceous to the Late Oligocene (Choukroune et al., 1989 and references therein). The Mauléon basin, located in the western part of the North Pyrenean Zone, consists of folded Mesozoic sedimentary units, thrust northward during the Tertiary along the Saint-Palais Thrust and the North-Pyrenean Frontal Thrust (Fig. 1). The basin is a Late Aptian to Albo-Cenomanian sag basin interpreted as a hyper-extended rift basin formed above a low-angle extensional detachment system, which is identified on the northern flank of the Labourd-Ursuya massif (Jammes et al., 2009) and at the base of the Igountze-Mendibelza massif (Johnson and Hall, 1989). In such a hyper-extended system, middle-lower crustal rocks and the SCLM were exhumed (Jammes et al., 2009; Masini et al., 2014), but age constraints on the timing of exhumation are still lacking. The only age associated to this extension phase is obtained in the eastern part of the Mauléon basin, where a gabbroic dyke, intruding the exhumed mantle body of Urdach, is sealed by Cenomanian sediments (Jammes et al., 2009; Debroas et al., 2010), and yields a relative flat Ar-Ar on biotite spectrum in the 105-108 Ma range (Masini et al., 2014).

Alkaline magmatism, high-temperature (up to $600^{\circ} \mathrm{C}$ ) low-pressure (HT-LP) metamorphism (Montigny et al., 1986; Golberg and Leyreloup, 1990), and hydrothermal fluid circulation associated with talc-chlorite mineralization (Boulvais et al., 2006) are observed elsewhere in the North Pyrenean Zone. These constraints indicate a heating episode from $110 \mathrm{Ma}$ to $85 \mathrm{Ma}$ (Montigny et al., 1986). Raman spectroscopy of carbonaceous material (RSCM) shows that the Albian to Cenomanian series of the Mauléon basin experienced shallow to mid-crustal temperatures of 180 to $295^{\circ} \mathrm{C}$ (Clerc and Lagabrielle, 2014). Determining whether these temperatures reflect thinning processes is not trivial and requires a thermal modeling approach. 
An important delay occurred between the onset of plate convergence at 83 Ma, (chron A34) used in plate reconstructions (Rosenbaum et al., 2002) and the exhumation in the belt recorded from $\sim 50 \mathrm{Ma}$ to $\sim 20 \mathrm{Ma}$, as constrained by low-temperature thermochronological data mainly in the Axial Zone (Yelland, 1990, 1991; Morris et al., 1998; Fitzgerald et al., 1999; Sinclair et al., 2005; Jolivet et al., 2007; Maurel et al., 2008; Gunnel et al., 2009; Metcalf et al., 2009). Time-temperature history (burial, heating and cooling) during the initial accretionary stage are therefore largely unknown. It may involve underestimated competing cooling processes such as syn-orogenic thermal relaxation or cooling by underthrusting as suggested recently in Taiwan (Mesalles et al., 2014).

\section{Sampling and methods}

\subsection{Strategy}

Determining thermal histories of crustal rocks is classically done using multiple lowtemperature thermochronometers on bedrock samples, but, in the Pyrenees, published bedrock low-temperature data are only consistent with episodes of collision-related cooling. To gain resolution on syn- to post-rift time-temperature history, a direct approach relies on examining syn-rift basins that recorded both extension and compression in the North Pyrenean Zone. In this aspect, the Mauléon basin is suitable as it experienced temperatures in the $110-295^{\circ} \mathrm{C}$ range (Fig. 1A). Its time-temperature evolution may therefore be resolved by combining zircon fission-track (ZFT) and (U-Th-Sm)/He (ZHe) thermochronology, which have their Partial Annealing Zone and Partial Retention Zone (PRZ) between $160-270^{\circ} \mathrm{C}$ and $140-$ $220^{\circ} \mathrm{C}$, respectively (e.g. Brandon et al., 1998; Guenthner et al., 2013). When zircons reside in these temperature intervals, the resulting ages are highly dependent on their timetemperature histories and diffusion kinetics. Recently published helium diffusion models reveal that apparent (U-Th-Sm)/He ages are controlled by the amount of $\alpha$-recoil damage, which is proportional to the effective U concentration [eU] (Flowers et al., 2009; Gautheron et al., 2009; Guenthner et al., 2013). Following these models, the thermal history explaining these ZHe age and eU correlations can be deduced from inverse modeling.

The dataset consists of five detrital sandstone samples from deep-water turbidites of the western part of the Mauléon basin, deposited at $101 \pm 4$ Ma in Albo-Cenomanian (Su-1, Ar2, Lu-1, Ch-1, and Mi-1, Fig. 1A, B). Two basement samples from a granitic intrusion (Itx-1) and gneiss (Lag-1) were collected (Fig. 1) to complete these data with apatite (AHe) and ZHe 
analyses, and to add independent constraints on collision-related cooling. Lu-1 was analysed with Raman Spectroscopy following the protocol developed by Lahfid et al. (2010). Samples were prepared at CRPG (Nancy, France). They were crushed and zircon and apatite grains were separated for low-temperature thermochronological analyses using standard heavyliquid and magnetic separation from the 61-280 $\mu \mathrm{m}$ fraction.

\subsection{Zircon Fission track analysis}

Zircon grains were handpicked for fission track dating and analysed at the thermochronology laboratory of ISTerre (Université Joseph Fourier, Grenoble). We used standard ZFT preparation procedures as described by Bernet and Garver (2005). Grains were mounted in a teflon sheet, polished to expose internal surfaces and etched with $\mathrm{NaOH}-\mathrm{KOH}$ at $228^{\circ} \mathrm{C}$ between 8 and 13 hrs. Irradiation was performed in the FRM II Research Reactor at the Technische Universität München (Germany) with CN1 dosimeter glasses and Fish Canyon Tuff age standards. Mica detectors used for external detector method (Gleadow et al., 1976) and standards were then etched in $48 \% \mathrm{HF}$ at $21^{\circ} \mathrm{C}$ for $18 \mathrm{~min}$. Counting was carried out on a Olympus BH2 optical microscope using FTStage 4.04 system of Dumitru (1993). Individual fission-track ages were obtained using zeta factors following approach of Hurford and Green (1983).

\subsection{Zircon (U-Th-Sm)/He analysis}

For (U-Th-Sm)/He dating, we handpicked 5 to 10 zircon grains per bedrock sample and between 60 and 110 zircon grains per detrital sample. Detrital zircons were mounted in epoxy and polished for future $\mathrm{U} / \mathrm{Pb}$ analyses. Among those zircons, we retrieved from the epoxy mounts between 20 and 35 zircons per detrital samples for (U-Th-Sm)/He analysis, chosen so as to represent the main peaks individualized in the $\mathrm{U} / \mathrm{Pb}$ age distributions. All theses detrital zircons were measured as single grains. Additionally, 4 to 5 replicates of 5 to 10 zircon grains were analysed in bedrock samples (Itx-1 and Lag-1). Zircon grains (prismatic to roundshaped, 0 to 2 pyramids, with an equivalent spherical radius ranging from 35 to $60 \mu \mathrm{m}$ ) were then measured, and loaded in Pt capsules for He extraction at CRPG. They were outgassed at $1500^{\circ} \mathrm{C}$ for $20 \mathrm{~min}$, and analyzed for He concentrations with a VG603 noble gas mass spectrometer (Pik et al., 2003; Godard et al., 2009). After total helium extraction, Pt capsules containing zircon grains were retrieved for $\mathrm{U}$, Th, and Sm content measurements at SARM (Nancy, France). Pt capsules were opened, and loaded in Pt crucibles along with ultra-pure 
$\mathrm{LiBO}_{2}$ and ultra-pure $\mathrm{B}(\mathrm{OH})_{3}$ for $2 \mathrm{hrs}$ at $990^{\circ} \mathrm{C}$ in an automatic tunnel oven. Then, the Pt crucibles were digested 12 hrs into acid. The preparation was then analysed using an inductively coupled plasma mass spectrometer. The overall precision of He ages determined

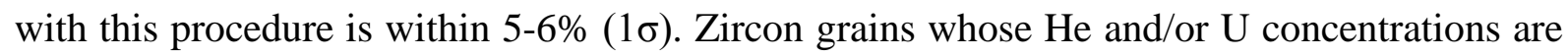
too close from the blank (e.g. for He content less than $1.10^{-13}$ moles and for $\mathrm{U}$ concentration in the solution less than $100 \mathrm{ppb}$ after blank correction) were not considered for this study. Zircon ages were corrected for $\alpha$-ejection $\left(\mathrm{F}_{\mathrm{T}}\right)$ following Ketcham et al. (2011) (Table DR2, DR3). To account for the abrasion of the detrital zircon single grains, we consider that we deleted $\sim 20 \mu \mathrm{m}$ (the mean stopping distance (Ketcham et al., 2011)) and the half of the mean width of our zircon grains $(\sim 45 \mu \mathrm{m})$. Following Reiners et al. (2007), we corrected $\mathrm{F}_{\mathrm{T}}$ considering an abrasion of $45 \mu \mathrm{m}$ for each detrital grain.

\subsection{Apatite (U-Th-Sm)/He analysis}

Apatites were prismatic, with 0 to 2 pyramids, and with an equivalent spherical radius ranging from 60 to $160 \mu \mathrm{m}$. We performed AHe analyses at Paris-Sud University (Orsay, France) on bedrock samples (Lag-1 and Itx-1, Fig. 1) following the procedure described by Fillon et al. (2013). Four single grain replicates were analyzed for Itx-1 and Lag-1 with $8 \%$ precision $(1 \sigma)$. AHe ages were corrected for $\alpha$-ejection following Ketcham et al. (2011) and apatites with outlier Th/U ratios were excluded (Table DR4).

\section{Results}

ZFT analyses performed on samples Su-1, Ar-2, Ch-1, and Mi-1 yielded 23 to 63 dated grains per sample (Table DR1). Each sample with an identical depositional age shows a similar age distribution. We therefore only present age component distributions for the combined samples $(n=171)$ (Fig. 2A). Most of the grains (97\%) are older than the depositional age, indicating very minor resetting after deposition.

We decomposed our age distribution into age components using DensityPlotter (Vermeesch, 2009, 2012). The software represents distribution of ages using KDE (Kernel Density Estimation), which is determined by stacks of Gaussian curves on top of each measurement, whose standard deviation is determined by the local probability density. Deconvolution for combined data returned three age components (errors are given as $\pm 2 \sigma$ ): two majors at $134 \pm$ 
46 (P1, 17\%) and $236 \pm 40$ (P2, 79\%), considered as cooling events, and a minor population at $1005 \pm 886$ Ma (4\%) characterized by a too important error to be statistically meaningful (Fig. 2A).

ZHe analyses were carried out on the same Su-1, Ar-2, Ch-1 samples and on Lu-1. Ten to 27 grains were dated per sample (Table DR2) and show similar ages and eU distributions. The age distribution from the combined data ranges from 36 Ma to $131 \mathrm{Ma}(\mathrm{n}=75$, Fig. 2B) and yields four age peaks at $39 \pm 4$ (16\%), $50 \pm 3$ (38\%), $68 \pm 4$ (33\%), and $116 \pm 7$ Ma (13\%). Most of these detrital ZHe grain ages (87\%) are younger than the depositional age, suggesting that they have been, at least, partially reset by post-deposition burial. We will test the timing and amount of burial and exhumation through numerical inversion of the data in the next section.

ZHe analyses on two bedrock samples from the Labourd-Ursuya massif (Lag-1 and Itx-1) give ages ranging from $51 \pm 5$ to $74 \pm 7 \mathrm{Ma}$, and from $61 \pm 6$ to $86 \pm 9 \mathrm{Ma}$, respectively (Table DR3). AHe single grain analyses performed on the same samples yield ages ranging from $42 \pm 3$ to $49 \pm 4$ Ma and from $35 \pm 3$ to $43 \pm 4$ Ma for Lag-1 and Itx-1, respectively (Table DR4).

\section{Thermal modeling of partially reset ages}

It has been demonstrated that $\alpha$-recoil damages associated to $U$ and Th decay, and their respective concentration (eU) could affect He diffusion in apatites (Shuster et al., 2006; Flowers et al., 2009; Gautheron et al., 2009). For high eU concentrations, the amount of $\alpha$ recoil damages increases with He retentivity and closure temperature. Guenthner et al. (2013) highlighted the same trend in zircons but only for relatively low concentrations of eU. For very high eU concentrations, the He retentivity rapidly decreases. These authors hypothesized that for very high eU content, the amount of $\alpha$-recoil damage is high enough so that damaged areas in the crystal are interconnected and form through-going fast diffusion pathways for He. Guenthner et al. (2013) showed that the evolution of He retentivity in zircons, which depends on the eU content, controls both variations of the closure temperature and individual annealing behaviors. This effect can lead to large ZHe age distributions, under a given timetemperature path. The non-random distribution of our ZHe age-eU dataset is supported by their statistical distribution in Figure 3 (see caption for details concerning the density function used) and suggests such a control. Originating from a dense zone of young ZHe ages and low- 
216 eU grains two opposite trends can be identified as ZHe-eU groups. A first group A (red area) consists in young ZHe ages (from 36 to $65 \mathrm{Ma}$ ) associated with a large eU distribution (from 400 to 4000 ppm). The group B (blue area) corresponds to older ZHe age (from 65 to 131 $\mathrm{Ma}$ ) associated with low eU values only (from 0 to $1100 \mathrm{ppm}$ ). Following Guenthner et al. (2013), the oldest ages could correspond to zircon grains that have been less resetted due to a higher closure temperature $\left(\sim 220^{\circ} \mathrm{C}\right)$. Such zircons require a longer residence time in the PRZ to be reset. In contrast, the young ZHe grain ages that display $\mathrm{eU}>1100 \mathrm{ppm}$ would correspond to a lower closure temperature of $<140^{\circ} \mathrm{C}$.

To determine the time-temperature paths of these zircon grains, we used the HeFTy soft (Ketcham, 2005) that includes the kinetic model of Guenthner et al. (2013). The limited number of grains (seven) that can be input in the HeFTy inverse modeling procedure do not allows direct inversion of the entire dataset and requires to identify representative individual ZHe age-eU pairs within the two groups observed in Figure 3. These two trends which originate in the red high density zone of Figure 3 can be easily and robustly described by a couple of representative samples. In order to describe the entire range of age-eU distribution, seven representative samples have been taken along the A and B groups and used for distinct sets of inversion. Various tests demonstrated that the use of representative samples is not an issue in this inversion procedure.

Because the A and B groups have been potentially controlled by distinct closure temperatures linked to the amount of radiation damage accumulated in the zircon grains (Guenthner et al. 2013) it is crucial to take into account the ZFT data obtained for these zircons in the inversion modeling. The ZFT data also exhibit two distinct populations characterized by peak ages at P1 ( 134 Ma) and P2 ( 236 Ma) that represent two independent cooling histories prior to deposition (at $\sim 100 \mathrm{Ma}$ ). At that time, the amount of accumulated damages was therefore significantly higher for the P2 population and could have triggered differential He diffusion when the sediments have been subsequently buried and re-heated. It is however not possible to directly relate one ZFT population with one ZHe ages group. Consequently both P1 and P2 ZFT populations have been used alternatively as input parameters for the inversion modeling. Four sets of inversion models have therefore been tested (Fig. 4), corresponding to the various combinations using ZFT populations (P1, P2) and ZHe ages groups (A, B). Models are characterized by: (i) different pre-deposition histories constrained by the P1 and P2 ZFT characteristics (134 $\pm 15 \mathrm{Ma} / 240 \pm 40^{\circ} \mathrm{C}$ and $236 \pm 20 \mathrm{Ma} / 240 \pm 40^{\circ} \mathrm{C}$ respectively), (ii) identical depositional age at $110 \mathrm{Ma}$, (iii) a free post-depositional time-temperature history inverted for 7 representative ZHe ages of groups A and B independently. To reproduce the 
250

251

252

253

254

255

256

257

258

259

260

261

262

263

264

265

266

267

268

269

270

271

272

273

274

275

276

277

278

279

280

partial reset signature of the ZHe data, we constrained the software to search post-deposition time-temperature paths from shallow to mid-crustal temperatures, corresponding to a range from $20^{\circ} \mathrm{C}$ and $200^{\circ} \mathrm{C}$. The inversion consisted of randomly testing 300,000 time-temperature paths for each model.

The P1-A model returned 439 acceptable and 180 good solutions. The P1-B model returned only 70 acceptable and no good solutions. The P2-A model only returned 35 acceptable and no good solutions. The P2-B model returned 405 acceptable and 62 good solutions. The best time-temperature path of each model corresponds to a ZHe age-eU correlation, which is compared to the data in Figure 4B. The P1-A model better fits the group A than the P2-A model, which fails to reproduce the data with eU $>2000 \mathrm{ppm}$. The P2-B model is in better agreement with the group B than the P1-B model. Models P1-A and P2-B return the best correlations between eU and ZHe ages that reproduce the data (Fig. 4B). We infer that all Albo-Cenomanian ZHe detrital data are obtained by the combination of these two timetemperature models (Fig. 4).

These models show a consistent post-100 Ma thermal history. In particular, time-temperature paths of our zircon grains are consistent with heating to temperatures of $\sim 180^{\circ} \mathrm{C}$ soon after $\sim 100 \mathrm{Ma}$ at an average heating rate of $\sim 5^{\circ} \mathrm{C} / \mathrm{Myr}$. Several of these pathways show a nearly isothermal stage established at $\sim 80$ Ma which lasted maximum $\sim 30$ Myr. This heating/isothermal stage was followed by a relatively rapid cooling stage from 50 Ma to present $\left(\sim 3^{\circ} \mathrm{C} / \mathrm{Myr}\right)$. This cooling path is not very precisely described by the inverse modeling because of the lack of additionnal lower temperature thermochronometers.

\section{1D thermo-kinematic modeling of rift-to-collision evolution}

The results of modeling (Fig. 4) show that the Albo-Cenomanian zircon grains were heated to a temperature of $\sim 180^{\circ} \mathrm{C}$ during the post-breakup evolution of the Mauléon basin. To constrain the geothermal gradient associated with this heating episode, a few Myrs only after deposition of the sampled Albo-Cenomanian rocks (see Figure 4A), we first need to determine the thickness of the entire pile of sediments in the Mauléon basin. The complete burial history shown in Figure 5A was resolved by combining well data from different boreholes, including boreholes in the Arzacq basin, North of the Mauléon basin (for instance Lacq 301, Brunet (1984)), and wells drilled in the Mauléon basin. They are from South to North: Ainhice 1, Chéraute 1, Uhart-Mixe 1 and Saint-Palais 1 for the Triassic to Late 
281 Cretaceous history, and Lahontan 1bis, Lacq 301, and Nassiet 1 for the Late Cretaceous to the 282 Late Eocene deposits (Fig. 5B). Estimates of minimum and maximum thicknesses at time of deposition of the studied samples from 105 to $70 \mathrm{Ma}$ are indicated in Figure 1B. We estimate that a mean sediment thickness of $\sim 2 \mathrm{~km}$ was deposited above the studied samples during this period of time (Fig. 5A). A temperature of $180^{\circ} \mathrm{C}$ at $\sim 2 \mathrm{~km}$ depth, as suggested from the ZHe data, allows to define a geothermal gradient as high as $\sim 80^{\circ} \mathrm{C} / \mathrm{km}$ (assuming a surface temperature of $20^{\circ} \mathrm{C}$ ).

To examine the tectonic conditions that led to the observed cooling history, we consider two different end-member thinning processes (Figs. 6A, B, and 7) that are thought to embody most of the fundamental characteristics of rifted margins as summarized by Huismans and Beaumont (2011). A stepwise tectonic evolution from 130 Ma to 0 Ma of a lithosphere section below the Mauléon basin involves thinning through a rifting phase from the Early Barremian (130 Ma) until the Late Cenomanian (95 Ma) with a breakup occurring at $110 \mathrm{Ma}$. This is followed by inversion and underthrusting of the thinned lithosphere from 83 Ma until the Early Eocene (50 Ma) that marks the onset of crustal thickening and thrust-related exhumation. In order to test these two hypotheses, we adopt a 1D forward thermo-kinematic modeling approach. The thermochronological modeling showed that the Albo-Cenomanian series in the Mauléon basin were heated to a temperature of $\sim 180^{\circ} \mathrm{C}$, which was maintained during 30 Myrs (Fig. 4). We therefore attempt to retrieve from the model the time-depth evolution of the $180^{\circ} \mathrm{C}$ isotherm by varying thinning factors for crust and mantle. The thickness of the Mauléon sedimentary layers at time of deposition of Albo-Cenomanian is constrained by the subsidence history of the Mauléon basin defined in Figure 5A. We consider an initial thickness of $2 \mathrm{~km}$ of sediments above the continental crust that increases to a final thickness of $6 \mathrm{~km}$. The current Moho depth is estimated to $32 \mathrm{~km}$ in the region of the Mauléon basin (Daignieres et al., 1982; Jammes et al., 2010; Chevrot et al., in revision) leading to consider a final thickness of continental basement of $28 \mathrm{~km}$. We hypothesize that the thickness of the continental basement was the same before the onset of rifting. At the initial and final stages we consider that the lithosphere is in equilibrium stage and adopt a typical thickness value for a Phanerozoic continental lithosphere of $130 \mathrm{~km}$ (e.g., Poudjom Djomani et al., 2001) (Fig. 6).

311 In model A, the crust is thinned until breakup occurs (Fig. 6A). After crustal breakup, the SCLM is thinned and exhumed at the base of the Mauléon basin, according to variable amount of thinning factors $\beta_{\mathrm{A}}$ ranging from 4, 10 and higher (SCLM breakup). In model B, the SCLM is thinned until its breakup, leading to the rise of hot asthenosphere below the 
continental crust (Fig. 6B). Similarly to model A, model B is run for the same variable amount of thinning factor $\beta_{\mathrm{B}}$ for the continental crust. We also test the impact of the thickening of the SCLM (model A) or the crust (model B), after convergence initiated at 83 Ma, on the thermal evolution of Mauléon basin. This was performed by taking into account the accumulation of syn-orogenic sediments under local isostatic conditions. For both scenarios, the role of transient diffusive heat relaxation and advection related to basin subsidence history, isostasy and rock uplift is quantified. It accounts for realistic diffusivity and heat production distribution. To simulate the effect of a high thermal conductivity layer represented by the Triassic evaporites, the basin rests above a $1 \mathrm{~km}$-thick Triassic salt layer, which thickness is kept constant during the simulation. Although fluid circulations may play a key role during extension by maintaining high temperatures below the basin and favoring heat transfers, we kept the model as simple as possible so as to depend on a minimum of unknown parameters, as the basin evolved from extensional to compressional tectonic settings.

Model results show that the depth of the $180^{\circ} \mathrm{C}$ isotherm is controlled to first order by the amount of thinning of the SCLM (Fig. 7). This effect is most significant for model A (SCLM exhumation) in which the depth of the $180^{\circ} \mathrm{C}$ isotherms is seen to vary between 1 and $5 \mathrm{~km}$ as a function of the amount of thinning. In the model $\mathrm{B}$, this is less apparent because the asthenosphere is kept closer to the surface (from $7 \mathrm{~km}$ depth to surface depending on the $\beta$ considered) during all the experiment.

Prior to crustal breakup at $110 \mathrm{Ma}$, model A and B show very different thermal responses to rifting. An upward deflection of isotherms is observed for the model B, while model A indicates a cooling phase before heating. Thermal evolution in model B reflects the upward advection of the base of the lithosphere during thinning, which is maximum when the SCLM breakup is achieved. In model A, a delay is observed between the onset of crustal and SCLM breakup. This reflects the loss of the radiogenic heat source caused by crustal breakup, which is not instantaneously compensated by advection of heat caused by SCLM thinning.

342 During the inversion phase, the $180^{\circ} \mathrm{C}$ isotherms are maintained to the same depth from 95 to 34350 Ma for both models (red and black curves on figure 7) corresponding to a limited linear 344 increase of heat with respect to the base of the Mauléon basin. When we account for the 345 thickening of the SCLM or the crust below the basin during the underthrusting phase, the $180^{\circ} \mathrm{C}$ isotherms remain flat from $83 \mathrm{Ma}$ to $50 \mathrm{Ma}$ for both models $\mathrm{A}$ and $\mathrm{B}$. The progressive 
deepening of the $180^{\circ} \mathrm{C}$ isotherms after 50 Ma reflects the primary effect of thermal relaxation and the deepening of the SCLM, relative to the heat advection due to erosion.

\section{Discussion}

\subsection{Comparison between thermochronological data and thermo-kinematic modeling}

In this study, we focus on the thermal history of the Mauléon basin from Albo-Cenomanian times until today. However, because our ZFT ages are only slightly reset (10\%) with no significant influence on age populations, we can assume that P1 ( 134 Ma) and P2 ( 236 Ma) reflect two cooling events that occurred prior to deposition. The P1 cooling event appears to be consistent with extension recorded in the Early Cretaceous at ca. 145-132 Ma (Vergés and García-Senz, 2001). Zircons cooled between 150 Ma and 100 Ma (P1) from mid-crustal to surface temperatures may reflect denudation in the footwall of a rolling-hinge normal fault (Axen and Baertley, 1997). The P2 event is also coherent with a magmatic (Rossi et al., 2003) and/or exhumational event during the Triassic, as recognized in Albian sediments in the southern Pyrenees (Filleaudeau et al., 2011).

On the other hand, ZHe age data show a complex and large distribution from 36 to $131 \mathrm{Ma}$ with most of them younger than depositional age. This is typical of partial resetting and, for a given duration of thermal event, its amplitude could have been controlled by various factors including: (i) the size of the grains, (ii) the initial age distribution of grains, (iii) the position in the PRZ during re-heating, (iv) the residence time above the PRZ and the amount of $\alpha$ recoil damages accumulated before re-heating (Guenthner et al., 2013). Inversion of ZHe data with thermochronological models (Fig. 4) suggests that zircon grains have been heated to temperatures up to $\sim 180^{\circ} \mathrm{C}$ soon after deposition $\sim 100 \mathrm{Ma}$ ago (Fig. 4A, B). This is consistent with our thermo-kinematic models $\mathrm{A}$ and $\mathrm{B}$ showing that the basin was already hot at the end of the rifting phase (95 Ma), due to upward deflection of the $180^{\circ} \mathrm{C}$ isotherm reaching the depth of the Albo-Cenomanian series at $2 \mathrm{~km}$ for $\square=10$ or higher (Fig. 7). After this heating phase, both our thermochronological models P1-A and P2-B require that zircon grains were maintained at this temperature of $180^{\circ} \mathrm{C}$ through a nearly isothermal stage until $50 \mathrm{Ma}$. This period corresponds to the inversion phase of the thermo-kinematic models, where the $180^{\circ} \mathrm{C}$ isotherm depth remains constant from 95 Ma to 50 Ma. 
The youngest ZHe population from 60 to $40 \mathrm{Ma}$ is associated to the largest eU concentration distribution (from $\sim 0$ to 4000 ppm, Fig. 3) and corresponds to the lower limit of the He-PRZ (closure temperature lower or equal to $140^{\circ} \mathrm{C}$, Guenthner et al., 2013). These youngest ages are directly related to the main episode of cooling that affected the Mauléon basin since the Eocene. This is consistent with our thermo-kinematic models that indicate a progressive cooling driven by mantle subduction and thermal relaxation during the orogenic phase (Fig. 6). This directly led to the compensation of the hot thermal anomaly previously emplaced, as plate collision and crustal thickening initiated at 50 Ma. In the absence of very-lowtemperature thermochronological constraints, the results of the inversion models (Fig. 4A) do not lead to precise t-T scenario concerning this late phase of cooling. Whether such cooling through the He-PRZ of zircons was mostly achieved early (50 - $40 \mathrm{Ma}$ ) and driven by thermal relaxation or whether part of this cooling occurred later in the Pyrenean orogenesis (40 - 25 $\mathrm{Ma}$ ) and was driven by exhumation is not precisely expressed in the models. However thermo-kinematic models conducted in this study clearly demonstrate that thermal relaxation during exhumation, following transient upward deflection of isotherms, represent a significant cooling process that must be taken into account in the interpretation of thermochronological data in this range of temperature. In the Pyrenean belt this is particularly true for the North Pyrenean Zone which experienced large-scale hyper-extension related high geothermal gradients.

Our simple approach did not allow the evaluation of the role of the fluids effect in the Mauléon basin, but the good agreement between model and data suggests its role might be minor at least from a thermal perspective. However, fluid flow and serpentinization of the exhumed mantle in such settings may be prominent processes allowing the localization of deformation during extension.

\subsection{Implications for the evolution of the Pyrenees}

After deposition, Albo-Cenomanian zircon grains were heated to a temperature of $\sim 180^{\circ} \mathrm{C}$ during the post-breakup evolution of the Mauléon basin. At this time, the basin was presumably floored by the exhumed mantle as shown by geological evidences summarized in Jammes et al. (2009): reworked granulites and mantle peridotites in Albian sediments, and tectonic relationship with SCLM exhumation. These geological data best support a model A hyper-extended rift basin (Fig. 6A) even if both models A and B rift basins reproduce the thermal history of the basin (Fig. 6A, B). This heating phase was characterized by a 
geothermal gradient as high as $\sim 80^{\circ} \mathrm{C} / \mathrm{km}$ consistent with RSCM temperatures $\left(180^{\circ} \mathrm{C}\right.$ to $295^{\circ} \mathrm{C}$ ) and HT-LP metamorphism of pre-Cenomanian sedimentary units (Fig. 1).

411 Heating in the basin ceased rapidly from 80 Ma on. This stage was followed by a rather isothermal period that initiated coevally with the onset of plate convergence at 83 Ma. Both temperature and geothermal gradient were then kept at a high level for $30 \mathrm{Myrs}$, until $50 \mathrm{Ma}$ when cooling/exhumation started associated with mountain building. The persistence of high surface thermal flow and geothermal gradients 18 Myrs after sea-floor spreading has been reported in present-day rifted margins of the Gulf of Aden (Lucazeau et al., 2010; Rolandone et al., 2013). In the case of the Mauléon basin, the temperature structure acquired during the rift phase prevailed at the earliest stage of continental accretion. This is in marked contrast with thermal evolution reported, e.g., in Taiwan (Mesalles et al., 2014) where rapid underthrusting of the lower plate $(50-80 \mathrm{~mm} / \mathrm{yr})$ at onset of continental accretion led to downward deflection of isotherms. This cooling phase is not detected in the early accretionary prism stage of the Pyrenees. We interpret this difference as a consequence of limited lateral heat advection induced by a much slower plate convergence of only 3-4 mm/yr (Mouthereau et al., 2014).

Our result reveals that onset of shortening in the Mauléon basin occurred in an abnormally hot basin. Due to the absence of significant nappe stacking in the region, we argue that ductile shortening documented in the inverted rifted basin results from high temperatures inherited from rifting rather than syn-convergence burial. It is characterized by axial-planar and crenulation cleavages in folded Albian to Cenomanian units of the Mauléon basin that reveal ambient temperatures of $100-200^{\circ} \mathrm{C}$ (Choukroune, 1974), consistent with our models. Fission track analyses on the Labourd-Ursuya Massif yield two ages at $42.2 \pm 2.4$ Ma and $48.3 \pm 2.3 \mathrm{Ma}$ on apatites, and an age at $81.8 \pm 3.1$ Ma on zircons (Yelland, 1991). Thus, ZFT and ZHe ages from the Labourd-Ursuya Massif indicate initial cooling from probably deeper crustal temperatures at 80-50 Ma, showing a different thermal history from the Mauléon basin. AFT and AHe ages (ranging from $49 \pm 4 \mathrm{Ma}$ and $35 \pm 3 \mathrm{Ma}$ ) in the Western Pyrenees suggest that cooling/thermal relaxation of high temperatures after 50 Ma occurred synchronously with the North Pyrenean massifs in the Eastern and Central Pyrenees (Morris et al., 1998; Fitzgerald et al., 1999; Yelland, 1991), as a result of crustal thickening and erosion. The thermal relaxation observed after $50 \mathrm{Ma}$ in the Mauléon basin therefore appears related to a major and regional exhumational phase in the Pyrenees. Because erosion is one of the main agent in orogenic belts bringing heat closer to the surface it may seem counterintuitive that thermal relaxation occurred during the main exhumational phase. 
443 Processes other than erosion may therefore explain the thermal relaxation. Heat advection 444 recorded in the Mauléon basin remained limited first because only $2 \mathrm{~km}$ of basin sediments 445 were eroded since 50 Ma. In addition, our thermo-kinematic experiments (Fig. 6) show that 446 the emplacement the Mauléon basin onto a thicker and colder foreland lithosphere 447 compensates heating due to exhumation.

\section{8. Conclusions}

449 This study demonstrates that the analysis of low-temperature thermochronological constraints 450 performed on pre-/syn-rift sediments preserved in mountain belts is effective in resolving the 451 long-term post-rift and syn-convergence thermal evolution of rifted margins and hyper452 extended rift basins. When combined with thermal-kinematic models of rift-to-collision 453 evolution, our data allowed to test hypotheses on the thinning processes between crust and the 454 lithospheric mantle that cause the reconstructed time-temperature history.

455 Our low-temperature thermochronological data show that the sediment succession of the 456 Mauléon basin recorded a phase of heating following breakup in the Albo-Cenomanian as a 457 result of extreme extension. The Albo-Cenomanian sandstones reached temperatures of $458180^{\circ} \mathrm{C}$ at only $\sim 2 \mathrm{~km}$ depth, corresponding to a geothermal gradient of $\sim 80^{\circ} \mathrm{C} / \mathrm{km}$.

459 Using this approach we demonstrate that the thermal structure of the Mauléon basin is 460 consistent with extreme thinning, although the relative thermal effect of breakup of the SCLM 461 and crustal breakup can hardly be differentiated. The temperature anomaly inherited from 462 extreme thinning lasted 30 Myrs, from 80 Ma to 50 Ma. This inherited thermal anomaly 463 explains ductile shortening identified in the inverted basin. It provides a mechanism for 464 explaining the observations of abnormally high temperatures (relative to inferred burial), syn465 convergence MT or HT metamorphism and ductile deformation in post-rift sediments. On the 466 other hand, these tectono-metamorphic characteristics are diagnostic of highly extended rift 467 basin inverted relatively soon after its emplacement. Thermal relaxation of the rift-related 468 heat anomaly occurred during the main stage of the orogenic development, when the hyper469 extended rift basin was thrusted over the colder and thicker European plate 50 Myrs ago. 470 The Pyrenees give us a vivid example of how high temperatures inherited from the rifting can

471 affect the thermal structure of the early stages of the collision, and how these temperatures are 472 relaxed during the late stage of orogenic processes. 
473

474

475

476

477

478

479

480

481

482

483

484

485

486

487

488

489

490

491

492

493

494

495

496

497

498

499

500

\section{Acknowledgments}

This study was supported by French National Research Agency (ANR Project PYRAMID). We thank G. Manatschal and R.S. Huismans for constructive discussions. We also thank the staff of the different laboratories (CRPG, SARM, ISTerre, IDES) for welcoming us and for their precious help during data acquisition. Comments by two anonymous reviewers have been helpful in clarifying some points of the manuscript. This is CRPG contribution number 2344.

\section{Appendix}

The code of our 1D thermo-kinematic model solves the transient heat advection diffusion equation (A1), including heat production in one dimension:

$$
-\frac{\partial}{\partial z} k \frac{\partial T}{\partial z}+\rho C p v_{z} \frac{\partial T}{\partial z}=\rho C p \frac{\partial T}{\partial t}+\rho H
$$

Density, $\rho$, heat capacity, $C p$, heat production $H$ and the heat conductivity, $k$, are given constant values for each rock type and are listed in Table A1. The solution is obtained using a standard implicit in time centered finite difference scheme at each time step. However, in order to allow for advection of the $1330^{\circ} \mathrm{C}$ isotherm, or to allow for erosion and sedimentation, the model domain is remeshed at every time step.

The material advection parameter is treated independently of the mesh using pre-computed level-set functions that define the limit between each material phase (sediment, basement crustal rocks, mantle rocks), excluding artificial diffusion of material properties with time.

In the models, we assume that velocity, $v z$, in the rock column can be interpolated linearly between each petrologic interface. Beneath the lowest interface, velocity is constant and equal to the velocity of that interface. This ensures that the $1330^{\circ} \mathrm{C}$ isotherm imposed at the base of the model is not tight to rock uplift and allows for thermal relaxation to occur. Similarly, to enable effects of rock uplift or sedimentation, the $20^{\circ} \mathrm{C}$ isotherm is imposed at the surface of the Earth, but velocity at the surface is equal to that of the shallowest rock interface.

Initial conditions are obtained by solving the heat diffusion equation (A2) at steady state using defined material properties:

$$
-\frac{\partial}{\partial \mathbf{z}} k \frac{\partial T}{\partial \mathbf{z}}=\rho H
$$


501 This avoids artificial thermal re-equilibration, which would relate to ill-defined initial

502 geothermal gradients that would not be consistent with the material properties and particularly 503 heat production distribution.

\section{References}

505 Axen, G.J., Bartley, J.M., 1997. Field tests of rolling hinges: Existence, mechanical types and 506 implications for extensional tectonics. Journal of Geophysical Research 102, 2051520537, doi: 10.1029/97JB01355.

Bernet, M., Garver, J.I., 2005. Fission-track analysis of detrital zircon. Reviews in Mineralogy and Geochemistry 58, 205-238, doi: 10.2138/rmg.2005.58.8.

Boulvais, P., de Parseval, P., D’Hulst, A., Paris, P., 2006. Carbonate alteration associated with talc-chlorite mineralization in the eastern Pyrenees, with emphasis on the St. Barthelemy Massif. Mineralogy and Petrology 88, 499-526, doi: 10.1007/s00710-006-0124-x.

Brandon, M.T., Roden-Tice, M.K., Garver, J.I., 1998. Late Cenozoic exhumation of the Cascadia accretionary wedge in the Olympic Mountains, northwest Washington State. Geological Society of America Bulletin 110, 985-1009, doi: 10.1130/00167606(1998)110.

Brunet, M.F., 1984. Subsidence history of the Aquitaine Basin determined from subsidence curves. Geological Magazine 121, 421-428, doi: 10.1017/S0016756800029952.

Chevrot, S., Villaseñor, A., Sylvander, M., PYROPE Working Group, 2014. High resolution of the Pyrenees and Massif Central from the data of the PYROPE and IBERARRAY portable array deployments. Journal of Geophysical Research, in revision.

Choukroune, P., 1974. Structure et evolution tectonique de la Zone Nord-Pyrénéenne. Analyse de la deformation dans une portion de chaîne à schistosité vertical. Ph.D. thesis, Université Des Sciences et Techniques du Languedoc, Montpellier, 276 p.

Choukroune, P., ECORS Team, 1989. The ECORS Pyrenean deep sismic profile reflection data and the overall structure of an orogenic belt. Tectonics 8, 23-39, doi: 10.1029/TC005i002p00023.

Clerc, C., Lagabrielle, Y., 2014. Thermal control on the modes of crustal thinning leading to mantle exhumation. Insights from the Cretaceous Pyrenean hot paleomargins. Tectonics, doi : 10.1002/2013TC003471, accepted.

Clerc, C., Lagabrielle, Y., Neumaier, M., Reynaud, J.Y., and De Saint Blanquat, M., 2012. Exhumation of subcontinental mantle rocks : evidence from ultramafic-bearing clastic 

deposits nearby the Lherz peridotite body, French Pyrenees. Bulletin de la Société Géologique de France, 183, 443-459, doi: 10.2113/gssgfbull.183.5.443.

Daignières, M., Gallart, J., Banda, E., Hirn, A., 1982. Implications of the seismic structure for the orogenic evolution of the Pyrenean range. Earth and Planetary Science Letters 57, 88100, doi : 10.1016/0012-821X(82)90175-3.

Debroas, E.J., Canérot, J., Bilotte, M. 2010. Les Brèches d’Urdach, témoins de l'exhumation du manteau pyrénéen dans un escarpement de faille vraconnien-cénomanien inférieur (zone nord-pyrénéenne, Pyrénées-Atlantiques, France). Géologie de la France 2, 53-64.

Dumitru, T.A., 1993. A new computer-automated microscope stage system for fission-track analysis. Nuclear Tracks and Radiation Measurements 21, 575-580, doi: 10.1016/13590189(93)90198-I.

Filleaudeau, P.Y., Mouthereau, F., Pik, R. 2011. Thermo-tectonic evolution of the southcentral Pyrenees from rifting to orogeny: insights from detrital zircon $\mathrm{U} / \mathrm{Pb}$ and (UTh)/He thermochronometry. Basin Research 23, 1-17, doi: 10.1111/j.13652117.2011.00535.x.

Fillon, C., Gautheron, C., Van Der Beek, P. 2013. Oligocene-Miocene burial and exhumation of the Southern Pyrenean foreland quantified by low-temperature thermochronology. Journal of the Geological Society, London 170, 67-77, doi: 10.1144/jgs2012-051.

Fitzgerald, P.G., Muñoz, J.A., Coney, P.J., Baldwin S.L., 1999. Asymmetric exhumation across the Pyrenean orogen: implications for the tectonic evolution of a collisional orogeny. Earth and Planetary Science Letters 173, 157-170, doi: 10.1016/S0012821X(99)00225-3.

Flowers, R.M., Ketcham, R.A., Shuster, D.L., Farley, K.A., 2009. Apatite (U-Th)/He thermochronometry using a radiation damage accumulation and annealing model. Geochemica et Cosmochimica Acta 73, 2347-2365, doi: 10.1016/j.gca.2009.01.015.

Gautheron, C., Tassan-Got, L., Barbarand, J., Pagel, M., 2009. Effect of alpha-damage annealing on apatite (U-Th)/He thermochronology. Chemical Geology 266, 157-170, doi: 10.1016/j.chemgeo.2009.06.001.

Gleadow, A.J.W., Hurford, A.J., Quaife, R.D., 1976. Fission track dating of zircon: improved etching techniques. Earth and Planetary Science Letters 33, 273-276, doi: 10.1016/0012821X(76)90235-1.

Godard, V., Pik, R., Lavé, J., Cattin, R., Tibari, B., De Sigoyer, J., Pubellier, M., Zhu, J., 2009. Late Cenozoic evolution of the central Longmen Shan, eastern Tibet: Insight from (U-Th)/He thermochronometry. Tectonics 28, TC5009, doi: 10.1029/2008TC002407. 
Golberg, J.M., Leyreloup, A.F., 1990. High temperature-low pressure Cretaceous metamorphism related to crustal thinning (Eastern North Pyrenean Zone, France). Contributions to Mineralogy and Petrology 104, 194-207, doi: 10.1007/BF00306443.

Guenthner, W.R., Reiners, P.W., Ketcham, R.A., Nasdala, L., Giester, G., 2013. Helium diffusion in natural zircon: Radiation damage, anisotropy, and the interpretation of zircon (U-Th)/He thermochronology. American Journal of Science 313, 145-198, doi: 10.2475/03.2013.01.

Gunnel, Y., Calvet, M., Brichau, S., Carter, A., Aguilar, J.P., Zeyen, H., 2009. Low long-term erosion rates in high-energy mountain belts: insights from thermo- and biochronology in the Eastern Pyrenees. Earth and Planetary Science Letters 278, 208-218, doi: 10.1016/j.epsl.2008.12.004.

Huismans, R.S., Beaumont, C., 2011. Depth-dependent extension, two-stage breakup and cratonic underplating at rifted margins. Nature 473, 74-79, doi: 10.1038/nature09988.

Hurford, A.J., Green, P.F., 1983. The zeta calibration of fission-track dating. Isotope Geoscience 1, 285-317, doi: 10.1016/S0009-2541(83)80026-6.

Jammes, S., Manatschal, G., Lavier, L., Masini, E., 2009. Tectonosedimentary evolution related to extreme crustal thinning ahead of a propagating ocean: Example of the western Pyrenees. Tectonics 28, TC4012, doi: 10.1029/2008TC002406.

Johnson, J.A., Hall, C.A., 1989. Tectono-stratigraphic model for the Massif D’IgountzeMendibelza, western Pyrenees. Journal of the Geological Society 146, 925-932, doi: 10.1144/gsjgs.146.6.0925.

Jolivet, M., Labaume, P., Monié, P., Brunel, M., Arnaud, N., Campani, M., 2007. Thermochronology constraints for the propagation sequence of the south Pyrenean basement thrust system (France-Spaine). Tectonics 26, TC5007, doi: 10.1029/2006TC002080.

Ketcham, R.A., 2005. Forward and inverse modeling of low-temperature thermochronometry data. Reviews in Mineralogy \& Geochemistry 58, 275-314, doi: 10.2138/rmg.2005.58.11.

Ketcham, R.A., Gautheron, C., Tassan-Got, L., 2011. Accounting for long alpha-particle stopping distances in (U-Th-Sm)/He geochronology: Refinement of the baseline case. Geochemica et Cosmochimica Acta 75, 7779-7791, doi: 10.1016/j.gca.2011.10.011.

Lagabrielle, Y., Bodinier, J.L., 2008. Submarine reworking of exhumed subcontinental mantle rocks: field evidence from the Lherz peridotites, French Pyrenees. Terra Nova, 20, 11-21, doi: 10.1111/j.1365-3121.2007.00781. 
600

601

602

603

604

605

606

607

608

609

610

611

612

613

614

615

616

617

618

619

620

621

622

623

624

625

626

627

628

629

630

631

632

633

Lagabrielle, Y., Labaume, P., and De Saint Blanquat, M., 2010. Mantle exhumation, crustal denudation, and gravity tectonics during Cretaceous rifting in the Pyrenean realm (SW Europe): Insights from the geological setting of the lherzolite bodies. Tectonics, 29, TC4012, doi: 10.1029/2009TC002588.

Lahfid, A., Beyssac, O., Deville, E., Negro, F., Chopin, C., Goffé, B., 2010. Evolution of the Raman spectrum of carbonaceous low-grade metasediments of the Glarus Alps (Switzerland). Terra Nova 22, 354-360, doi: 10.1111/j.1365-3121.2010.00956.x.

Lucazeau, F., Leroy, S., Rolandone, F., D’Acremont, E., Watremez, L., Bonneville, A., Goutorbe, B., Düsünur, D., 2010. Heat-flow and hydrothermal circulation at the oceancontinent transition of the eastern gulf of Aden. Earth and Planetary Science Letters 295, 554-570, doi: 10.1016/j.epsl.2010.04.039.

Manatschal, G. 2004. New models for evolution of magma-poor rifted margins based on a review of data and concepts from West Iberia and the Alps. International Journal of Earth Sciences (Geologische Rundschau) 93, 432-466, doi: 10.1007/s00531-004-0394-7.

Masini, E., Manatschal, G., Tugend, J., Mohn, G., Flament, J.M., 2014. The tectonosedimentary evolution of a hyper-extended rift basin: the example of the Arzacq-Mauléon rift system (Western Pyrenees, SW France). International Journal of Earth Sciences (Geologische Rundschau), doi: 10.1007/s00531-014-1023-8.

Maurel, O., Monié, P., Pik, R., Arnaud, N., Brunel, M., Jolivet, M., 2008. The MesoCenozoic thermo-tectonic evolution of the Eastern Pyrenees: an ${ }^{40} \mathrm{Ar} /{ }^{39} \mathrm{Ar}$ fission track and (U-Th)/He thermochronological study of the Canigou and Mont-Louis massifs. International Journal of Earth Sciences (Geologische Rundschau) 97, 565-584, doi: 10.1007/s00531-007-0179-x.

Mesalles, L., Mouthereau, F., Bernet, M., Chang, C.P., Tien-Shun Lin, A., Fillon, C., and Sengelen, X., 2014. From submarine continental accretion to arc-continent orogenic evolution: The thermal record in southern Taiwan. Geology 42(10), 907-910, doi: 10.1130/G35854.1.

Metcalf, J.R., Fitzgerald, P.G., Baldwin, S.L., Muñoz, J.A., 2009. Thermochronology of a convergent orogeny: constraints on the timing of thrust faulting and subsequent exhumation of the Maladeta Pluton in the Central Pyrenean Axial Zone. Earth and Planetary Science Letters 287, 488-503, doi: 10.1016/j.epsl.2009.08.036.

Montigny, R., Azambre, B., Rossy, M., Thuizat, R., 1986. K-Ar study of Cretaceaous magmatism and metamorphism in the Pyrenees: Age and length of rotation of the Iberian Peninsula. Tectonophysics 129, 257-273, doi: 10.1016/0040-1951(86)90255-6. 
Morris, R.G., Sinclair, H.D., Yelland, A.J., 1998. Exhumation of the Pyrenean orogen: implications for sediment discharge. Basin Research 10, 69-85, doi: 10.1040/j.13652117.1998.00053.x.

Mouthereau, F., Watts, A.B., Burov, E., 2013. Structure of orogenic belts controlled by lithosphere age. Nature Geoscience Letter 6, 785-789, doi: 10.1038/NGEO1902.

Mouthereau F., Filleaudeau, P.Y., Vacherat, A., Pik, R., Lacombe, O., Fellin, M.G., Castelltort, S., Christophoul, F., Masini, E., 2014. Placing limits to shortening evolution in the Pyrenees: role of margin architecture and implications for the Iberia/Europe convergence. Tectonics.

Pik R., Marty, B., Carignan, J., Lavé, J., 2003. Stability of the Upper Nile drainage network (Ethiopia) deduced from (U-Th)/He thermochronometry: implications for uplift and erosion of the Afar plume dome. Earth and Planetary Science Letters 215, 73-88, doi: 10.1016/S0012-821X(O3)00457-6.

Poudjom Djomani, Y.H., O’Reilly, S.Y., Griffin, W.L., Morgan, P., 2001. The density structure of subcontinental lithosphere through time. Earth and Planetary Science Letters 184, 605-621, doi: 10.1016/S0012-821X(00)00362-9.

Reiners, P.W., Thomson, S.N., McPhillips, D., Donelick, R.A., Roering, J.J., 2007. Wildfire thermochronology and the fate and transport of apatite in hillslope and fluvial environements. Journal of Geophysical Research 112, F04001, doi: 10.1029/2007JH000759.

Rolandone, F., Lucazeau, F., Leroy, S., Mareschal, J.C., Jorand, R., Goutorbe, B., Bouquerel, H., 2013. New heat-flow measurements in Oman and the thermal state of the Arabian Shield and Platform. Tectonophysics 589, 77-89, doi: 10.1016/j.tecto.2012.12.034.

Rosenbaum, G., Lister, G.S., Duboz, C., 2002. Relative motions of Africa, Iberia and Europe during Alpine orogeny. Tectonophysics 359, 117-129, doi: 10.1016/S00401951(02)00442-0.

Rossi, P., Cocherie, A., Fanning, C.M., Ternet, Y., 2003. Datation U/Pb sur zircons des dolerites tholéiitiques pyrénéennes (ophites) à la limite Trias-Jurassique et relations avec les tufs volcaniques dits “infra-liasiques” nord-pyrénées. Comptes Rendus Geoscience 335, 1071-1080, doi: 10.1016/j.crte.2003.09.011.

Shuster, D.L., Flowers, R.M., Farley, K.A., 2006. The influence of natural radiation damage on helium diffusion kinetics in apatite. Earth and Planetary Science Letters 249, 148-161, doi: 10.1016/j.epsl.2006.07.028. 
Sinclair, H.D., Gibson, M., Naylor, M., Morris, R.G., 2005. Asymmetric growth of the Pyrenees revealed through measurement and modeling of orogenic fluxes. American Journal of Science 305, 369-406, doi: 10.2475/ajs.305.5.369.

Vergés, J., García-Senz, J., 2001. Mesozoic evolution and Cainozoic inversion of the Pyrenean Rift, in: Ziegler, P.A., Cavazza, W., Robertson, A.H.F., Crasquin-Soleau, S., (Eds.), Peri-Tethys Memoire 6, Pery-Tethyan Rift/Wrench Basins and Passive Margins, Mémoires Muséum National d'Histoire Naturelle 186, Paris, pp. 187-212.

Vermeesch, P., 2009. RadialPlotter: A Java application for fission track, luminescence and other radial plots. Radiation Measurements 44, 409-410, doi: 10.1016/j.radmeas.2009.05.003.

Vermeesch, P., 2012. On the visualization of detrital age distributions. Chemical Geology 312-313, 191-194, doi: 10.1016/j.chemgeo.2012.04.021.

Vielzeuf, D., Kornprobst, J., 1984. Crustal splitting and the emplacement of Pyrenean lherzolites and granulites. Earth and Planetary Science Letters 67, 87-96, doi: 10.1016/0012-821X(94)90041-4.

Yelland, A.J., 1990. Fission track thermotectonics in the Pyrenean orogen. Nuclear Tracks Radiation Measurements 17, 293-299, doi: 10.1016/1359-0189(90)90049-4.

Yelland, A.J., 1991. Thermo-tectonics of the Pyrenees and Provence from fission track studies. Ph.D. thesis, University of London.

\section{Figure Captions}

Figure 1: A) Geologic map of the study area. Red stars and circles depict the position of studied samples and samples from which RSCM temperatures were obtained (Clerc and Lagabrielle 2014, including one new estimate from this study (Lu-1), respectively. The extent of cleavage domain is shown as red dashed area. B) Synthetic lithostratigraphy of mesocenozoic successions of the Mauléon basin and layer thickness inferred from borehole data (Fig. 5B). C) Geological cross-section of the western part of the Mauléon basin, including the location of samples and the extent of cleavage domain, same as shown in A. Note that the ductile deformation domain is observed at the base of the basin. NPFT: North Pyrenean Frontal Thrust, SPT: Saint-Palais Thrust, GRH: Grand-Rieu High.

Figure 2: Results of thermochronological analyses and decomposition of statistically representative age component of Albo-Cenomanian detrital samples. A) ZFT results from Su- 
1, Ar-2, Ch-1, and Mi-1 samples. B) ZHe age distribution from Su-1, Ar-2, Ch-1, and Lu-1 samples.

Figure 3: The statistical distribution of our ZHe age-eU data (blue empty squares) is resolved from a 2D Kernel probability density function using a Parzen window approach (Matlab code available on request). Low eU content from 0 to $1100 \mathrm{ppm}$ correspond to a large distribution of ZHe ages from 65 Ma to $131 \mathrm{Ma}$ (group B in blue). These oldest ages are associated to a closure temperature of $\sim 220^{\circ} \mathrm{C}$. By contrast, high eU content (>1100 ppm) only show young ZHe ages from $36 \mathrm{Ma}$ to $65 \mathrm{Ma}$ (group $\mathrm{A}$ in red), corresponding to lower closure temperatures $\left(<140^{\circ} \mathrm{C}\right)$.

Figure 4: A) Time-temperature histories extracted from HeFTy inverse modeling constrained by ZFT data, ZHe age-eU pairs, and depositional ages, for each model (P1-A, P1-B, P2-A and P2-B). B) ZHe age-eU statistical distribution of Albo-Cenomanian detrital zircon grains. We compare the ZHe age-eU correlation corresponding to the best time-temperature path of each model with the data.

Figure 5: A) Total decompacted thickness of sediments in the Mauléon basin, as obtained by combining seven boreholes within or close to the Mauléon basin for maximum, minimum and weighted averaged (red curve) estimations. Temporal influence intervals resolved from each borehole is shown in grey. Vertical dashed lines represent the period of heating highlighted in model of Figure 4 and the horizontal dashed lines correspond to the thickness of sediments deposited during this period. A mean value of $2 \mathrm{~km}$ of sediments was deposited between 105 and 70 Ma. B) Map showing the location of the different boreholes.

Figure 6: 1D thermal-kinematic models tested for the Mauléon basin. A) Model A: crustal breakup at $110 \mathrm{Ma}$ and SCLM is thinned and exhumed to the base of the basin until $95 \mathrm{Ma}$. Dashed red lines on model A correspond to tests considering SCLM thickening from onset of convergence at $83 \mathrm{Ma}$ to mature collision and exhumation after 50 Ma. B) Model B: SCLM breakup occurs at $110 \mathrm{Ma}$ and the continental crust thins until $95 \mathrm{Ma}$, lying in contact with the asthenophere. Tested thinning factors $\beta_{\mathrm{A}}$ and $\beta_{\mathrm{B}}$ are 4,10 , and $\infty$ (breakup) in both models.

Figure 7: Comparison of the Mauléon basin burial history with the depth of the $180^{\circ} \mathrm{C}$ isotherm predicted from 1D rift-to-collision thermal models (A and B) shown in Figures 6A and 6B, respectively. Depth evolution of the Albo-Cenomanian deposits (grey) is distinguished from the Meso-Cenozoic successions (green) and water (blue). Depth of the 
$729180^{\circ} \mathrm{C}$ isotherms produced by different thinning factors $\left(\beta_{\mathrm{A}}\right.$ and $\left.\beta_{\mathrm{B}}\right)$ meets the position of the 730 studied samples relatively soon after breakup of the crust (models A and A') or mantle (model 731 B) at 110 Ma. The isotherm is kept at a constant depth after onset of tectonic inversion. C: 732 Crust, S: SCLM, A: Asthenosphere. 
Table A1.

Thermal and mechanical parameters considered for each type of rock in the model

$$
\text { Sedimentary cover Basement }
$$

\begin{tabular}{cccccc} 
& Deposits & Triassic salt & Continental crust & SCLM & Asthenosphere \\
\hline $\begin{array}{c}\text { Thermal conductivity } \mathrm{k} \\
\begin{array}{c}\mathrm{W} /(\mathrm{m} . \mathrm{K}) \\
\text { Heat capacity Cp }\end{array}\end{array}$ & 2.25 & 6.5 & 2.25 & 3.3 & 3.3 \\
$\begin{array}{c}\mathrm{m}^{2} /\left(\mathrm{m} . \mathrm{s}^{2}\right) \\
\text { Heat production H }\end{array}$ & 900 & 840 & 900 & 750 & 750 \\
$\mu \mathrm{W} / \mathrm{m}^{3}$ & 0.9 & 0 & 0.6 & 0.009 & 0.009 \\
$\begin{array}{c}\text { Density } \rho \\
\mathrm{kg} / \mathrm{m}^{3}\end{array}$ & 2500 & 2170 & 2800 & 3300 & 3300 \\
\hline
\end{tabular}




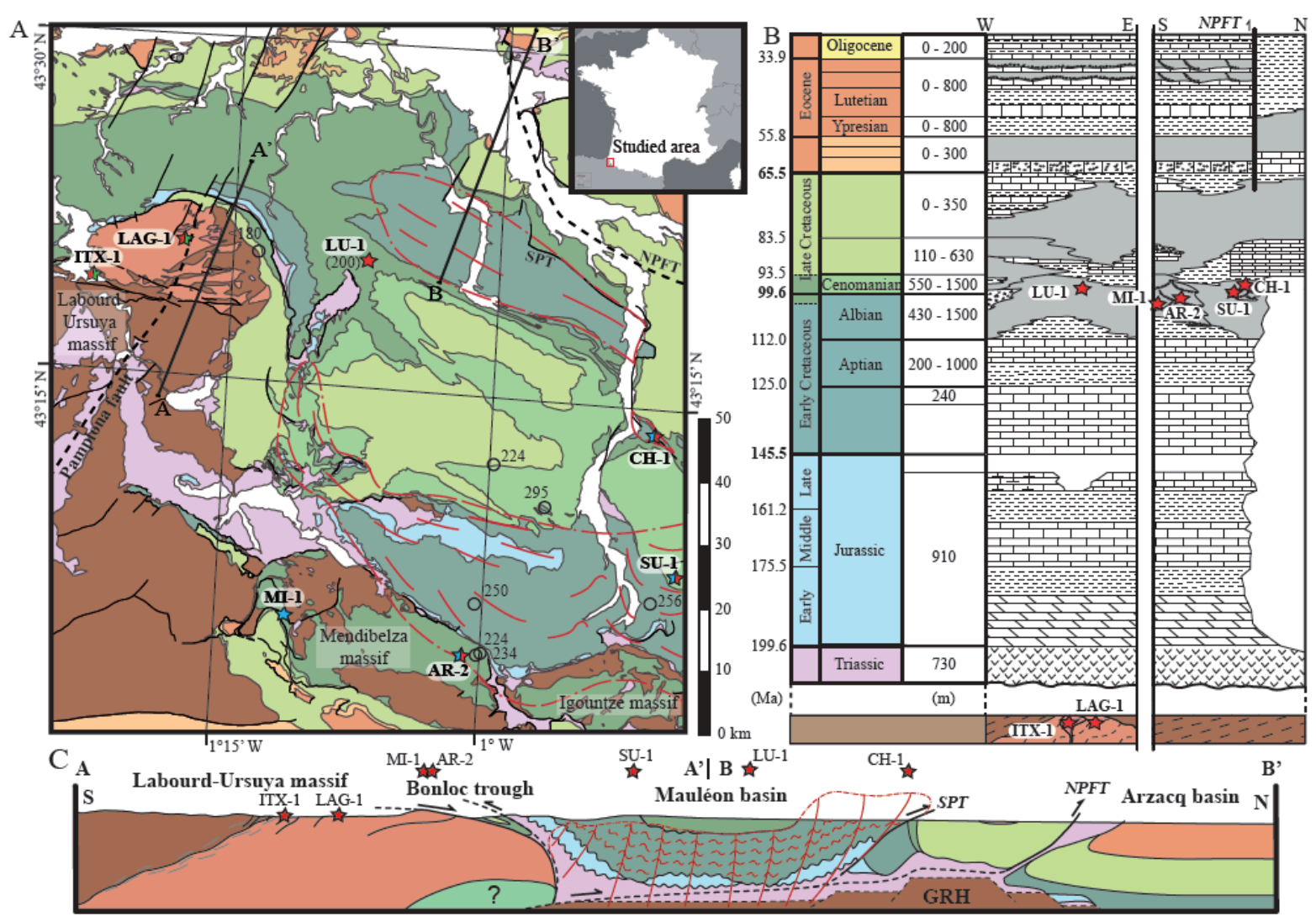

Figure 1 


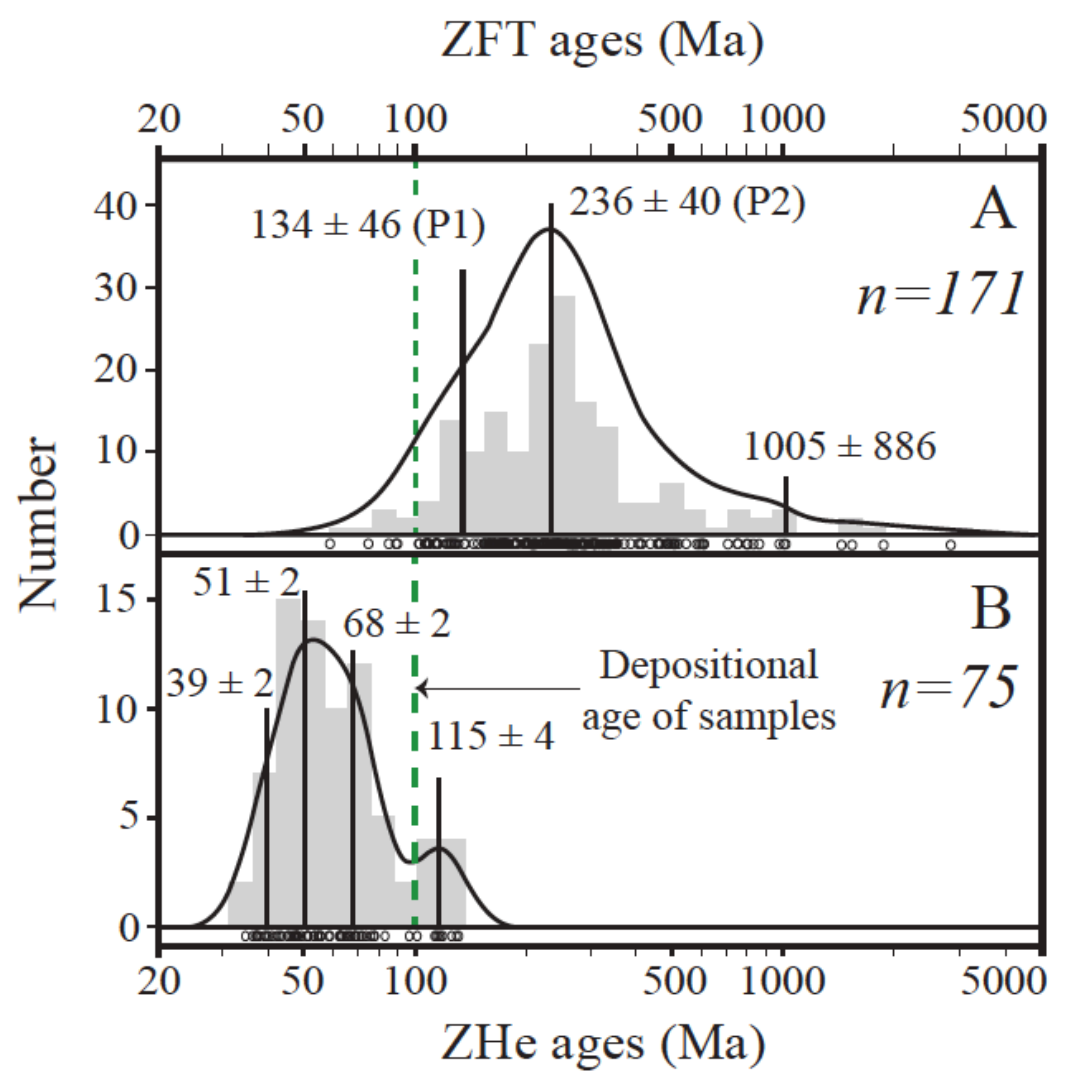

Figure 2 


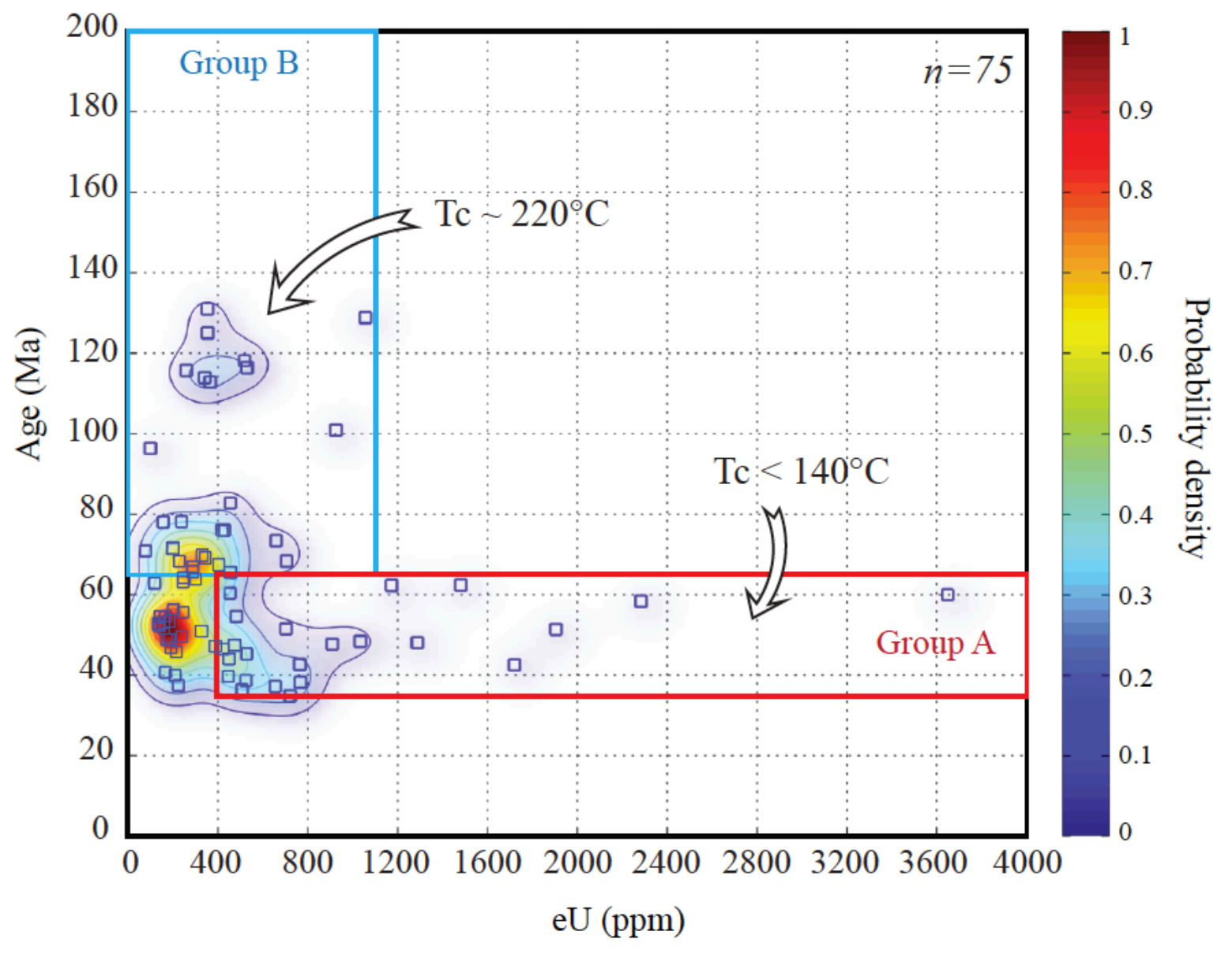

Figure 3 

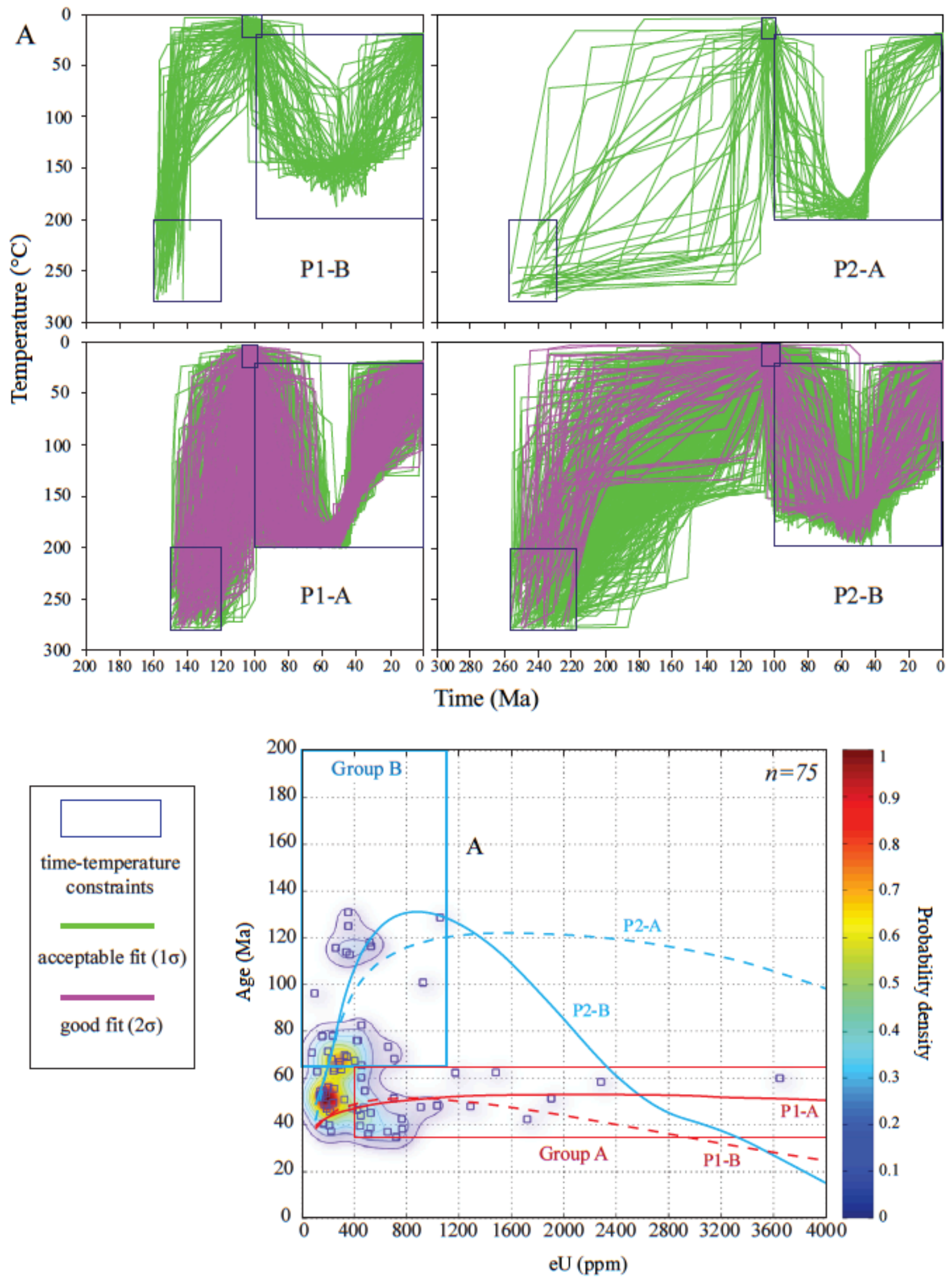

Figure 4 

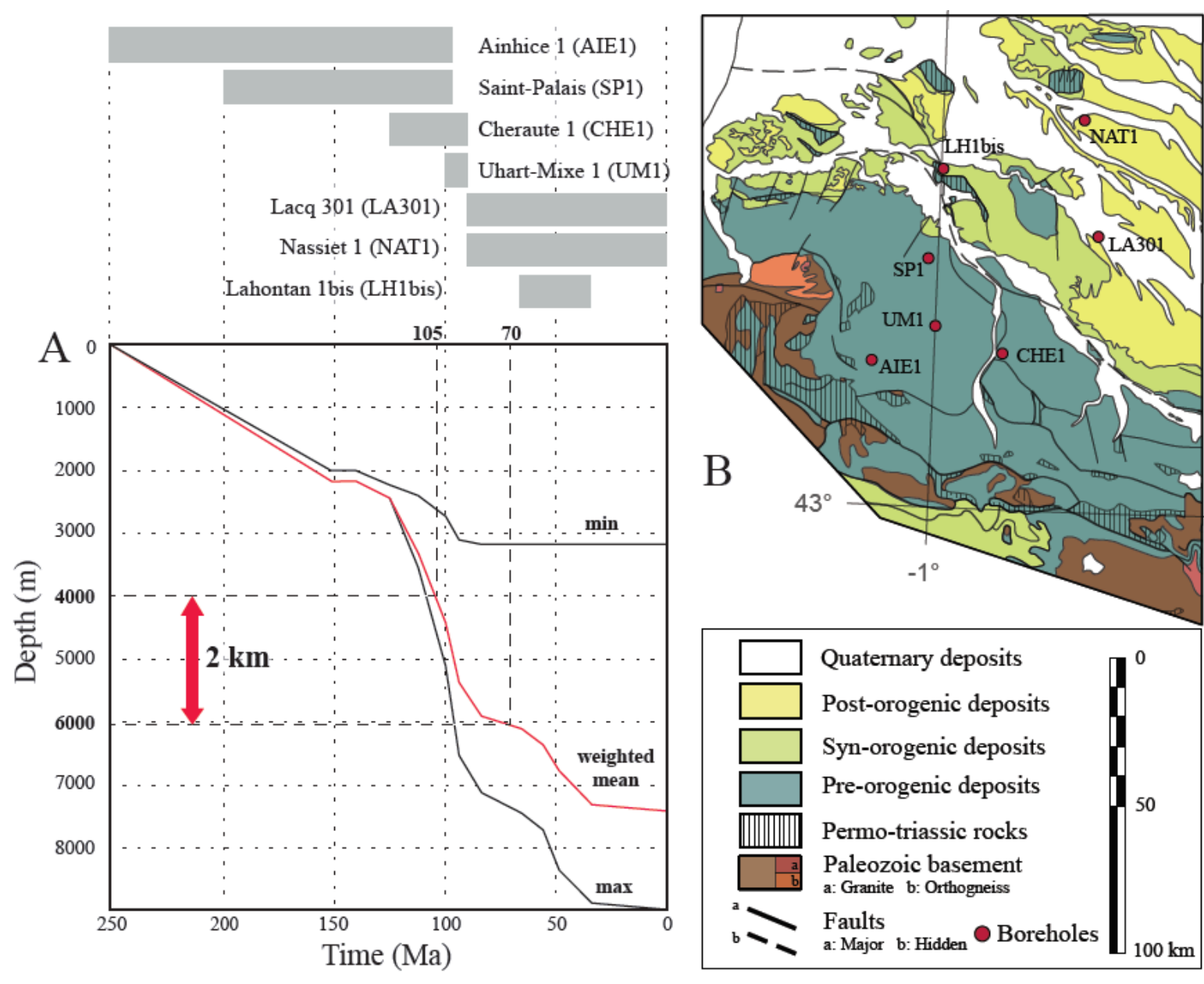

Figure 5 


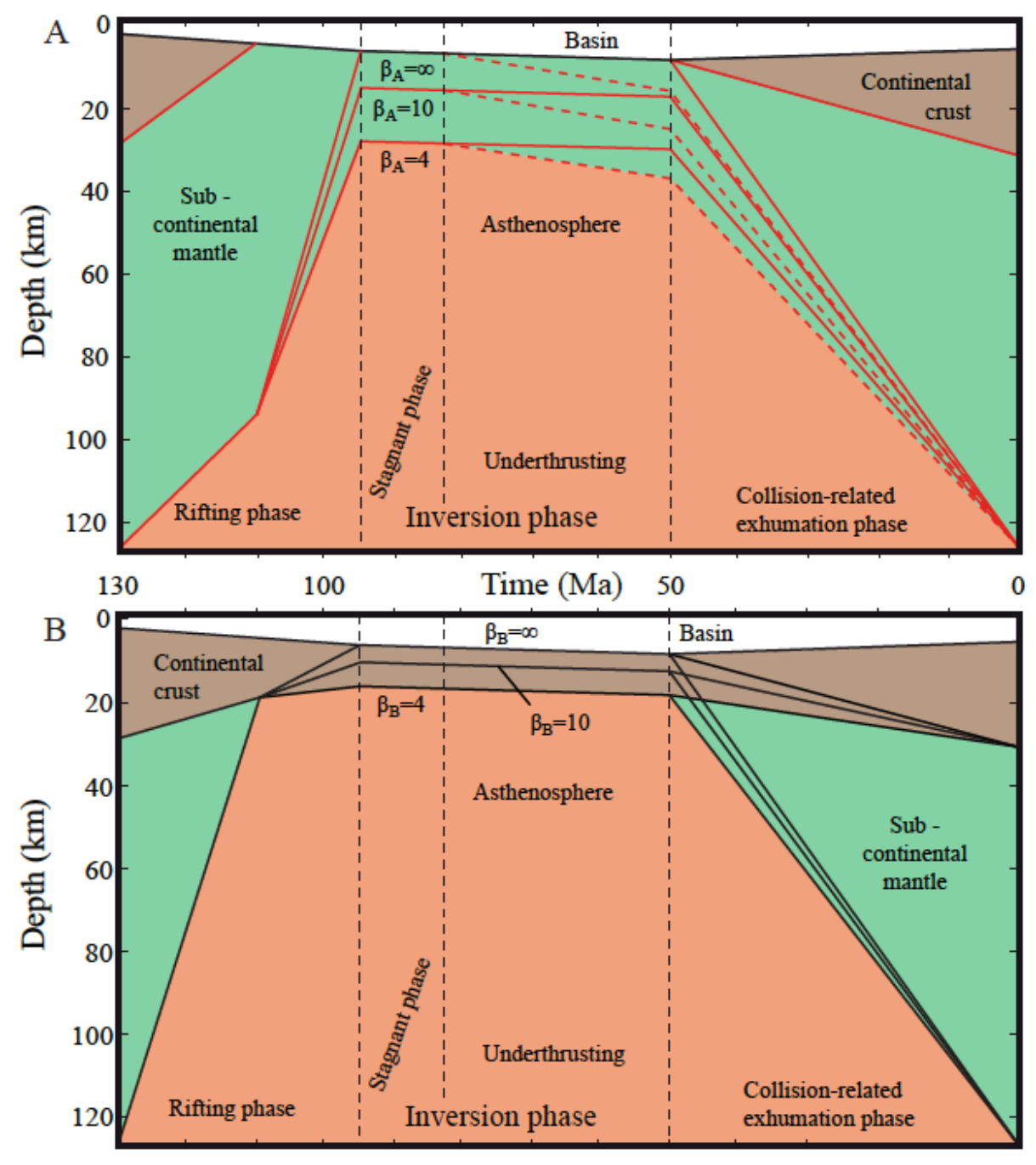

Figure 6 


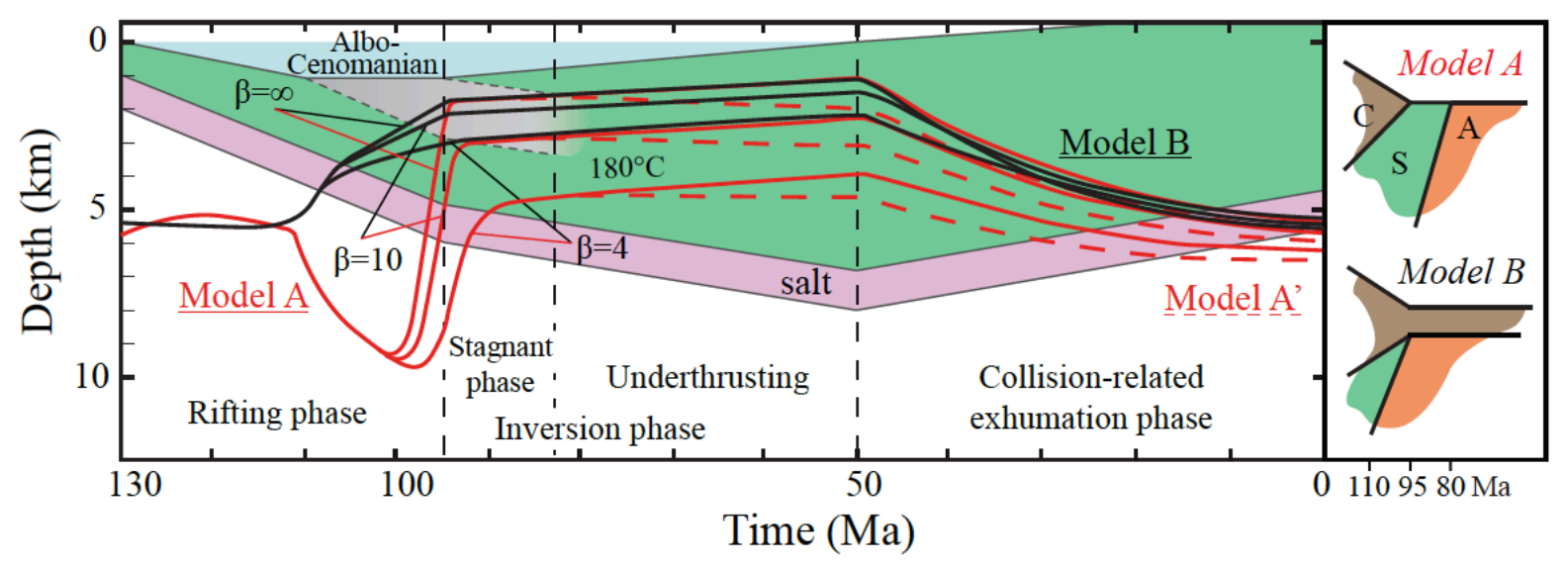

Figure 7 